\title{
The treatment and handling systems of industrial pollutants which generated and discharged into surface runoff from airports
}

\author{
Mindaugas Stankevičius, Rasa Stankevičienè \\ Department of Hydraulics Vilnius Gediminas technical university, Sauletekio ave. 11, LT-10223 Vilnius, Lithuania
}

\begin{abstract}
Industrial pollutants which generated and discharged into surface runoff from airports are aggressive for our surrounding environment and not adequately controlled. Over the years, the emission composition and quantities of Lithuania and foreign airports very changed. Airports and airlines deal with multiple objectives and are challenged with multiple constraints when it comes to airfield pavement and aircraft deicing and anti-icing. In this article presented abroad commonly used technologies and best practices to suspend or reduce the aggressive discharge of pollutants into surface runoff and creeks. There are several systems for the treatment and disposal of deicing runoff. This paper introduces proposed surface runoff treatment technology at Vilnius International Airport in Lithuania.
\end{abstract}

Keywords: pollution; runoff; airport; treatment technology.

\section{Introduction}

Industrial pollutants discharged into surface runoff on airports activity are commonly deicing and anti-icing products. Airports and airlines deal with multiple objectives and are challenged with multiple constraints when it comes to airfield pavement deicing and anti-icing. First, aircraft safety (and mobility) is of the highest priority, which at times demands large quantities of pavement deicing products (PDP) to be used for snow and ice control on airfield pavements. Because passenger and flight crew safety is of paramount importance, the aviation regulators and airframe and aircraft component manufacturers strive to ensure the highest standards possible. To ensure wintertime flight safety, large quantities of propylene glycol and ethylene glycol based products are used to deice aircraft. In addition, urea and a variety of acetate and formate based products are used to deice runways and taxiways.

There are several types of de-icing fluid, falling into two basic categories: 1) De-icing fluids - heated glycol diluted with water for de-icing and snow/frost removal, also referred to as Newtonian fluids (owing to their viscous flow similar to water). 2) Anti-icing fluid - unheated, undiluted propylene glycol based fluids that has been thickened (e.g. half-set gelatin), also referred to as non-Newtonian fluids (owing to their characteristic viscous flow), applied to retard the future development of ice or to prevent falling snow or sleet from accumulating.

However, the majority of these compounds exert significant oxygen demands when introduced into natural waterways. There is toxicity concerns associated with certain glycols and urea and with deicing and anti-icing fluid additives as well. Consequently, each year large quantities of propylene glycol (PG) and ethylene glycol based aircraft deicing fluids (ADF) are used to de-ice aircraft in the northern United States, Canada and north, and east Europe. In addition, urea and acetate/formate based runway deicers are in widespread use at most northerner airports. The purpose of aircraft deicing is to remove ice and snow from control surfaces (wings, rudders, and fuselages). Airplanes are designed based on the predictable effects of air flow over clean wings. The accumulation of ice, snow or frost on the wings disturbs this airflow and results in increased drag, increased stall speed, and may cause an abnormal pitch characteristic. Ice, snow or frost only as thick and rough as medium sandpaper can significantly reduce aerodynamic performance [1].

Second, environmental regulatory compliance is an important objective as a result of requirements of the National pollution discharge elimination system permits for surface runoff discharges. Many of airports getting difficulties to have good environment balance. The use of liquid glycol based and solid urea deicers has received particular scrutiny owing to the high biochemical oxygen demand (BOD) exerted on receiving bodies of water. Depleted oxygen levels can threaten

Corresponding author: Mindaugas Stankevičius. E-mail address: stankevicius.mi@gmail.com

http://dx.doi.org/10.3846/enviro.2014.096

(C) 2014 The Authors. Published by VGTU Press. This is an open-access article distributed under the terms of the Creative Commons Attribution License, which permits unrestricted use, distribution, and reproduction in any medium, provided the original author and source are credited. 
aquatic life, whereas the ammonia by-product of urea is toxic to aquatic organisms [2]. Although glycol-based deicers are increasingly less commonly used for pavement deicing, urea was still used by many busiest Europe and USA airports.

Third, materials compatibility between PDPs and the aircraft and airfield infrastructure is yet another objective. Some reports suggest that the use of modern PDPs, including alkali acetate and alkali formate products on aprons, runways, and taxiways may result in the need for more frequent maintenance and inspection for various aircraft and airfield infrastructure. In addition, more costly PDPs must be justified and programmed into operating budgets. The costs associated with both aircraft and airfield maintenance and alleviating the environmental impacts of PDPs must be balanced in decision making for deicing and anti-icing operations.

\section{Research subject and methodology}

Information used in this article was acquired through a comprehensive search of literature sources and from an existing project. Additional information, including the types of PDPs used by Vilnius airport and other foreign airports are collected from airport infrastructure managers, air carriers, deicing and anti-icing manufacturers, industry and government organizations. The search of information about treatment technologies of surface runoff contaminated with deicing and antiicing products was carried out using a variety of tools, including Google Scholar, Google, etc. Relatively limited information on in academic peer-reviewed literature was found. Especially grateful for the information provided by Zurich International Airport.

In 2010-2012 is implemented technical project „Airport surface runoff treatment plants“ on the ground of technical design specification of State Enterprise International Vilnius Airport and the instructions received during intermediary coordination, design conditions, engineering-geological studies, engineering topography.

\section{Treatment systems}

There are several systems for the treatment and disposal of deicing runoff. These systems are divided into three primary categories: off-site, onsite, and recovery options. The off-site category consists of systems where the airports surface runoff into a collection system or pay for trucking to a treatment/disposal facility. Off-site treatment of airport deicing surface runoff is usually accomplished by discharging deicing runoff through the sanitary sewer system to a wastewater treatment plant for treatment and disposal. The on-site category consists of aerobic and/or anaerobic treatment facilities or soil based schemes that can be constructed at the airport for the pretreatment or treatment and disposal of the deicing runoff. The recovery category utilizes filtration, reverse osmosis, and distillation to recover glycol from runoff. Recovery is usually only practical for runoff containing glycol concentrations greater than $5 \%$. The recovered glycol is reprocessed and sold for use in non-aircraft applications.

\subsection{Soil Treatment Systems}

Land application of wastewater is a proven technology and has been used for numerous types of industrial wastewaters [3]. Land application of aircraft deicing fluid surface runoff may be a good alternative for numerous airports since airports often have significant amounts of available land. Several studies have shown that glycols are readily degradable in soil [4-6]. McGahey and Bouwer [6] measured first order removal rates for the biodegradation of ethylene glycol in simulated subsurface environments. They found that microorganisms naturally present in the soil and the groundwater were able to biodegrade ethylene glycol, with short adaptation times (less than three days in most cultures). Even at low temperatures, half-lives of 0.2 to 0.9 days were measured. The soil treatment system is successfully used at Zurich airport in Switzerland.

\subsection{Aircraft Deicing Pads}

Because most aircraft deicing/anti-icing operations are conducted at passenger terminals and aircraft parking ramps, snow collected from these locations may be contaminated with ADF, as well as small amounts of pavement deicing/anti-icing agents. Consequently, snow dumps that are used for disposal of contaminated snow should include provisions for collecting or containing the contaminated melt water. Aircraft deicing pads are specially designed platforms used to collect contaminated wastewater generated during aircraft deicing and anti-icing operations. They are constructed from concrete, reinforced rubber or polypropylene mats and sometimes use inflatable air or foam berms to contain contaminated wastewater. At Albany International Airport in USA, for example, two concrete pads, each with its own drainage collection system, are used to store snow contaminated with deicing/anti-icing chemicals. As the snow melts, the melt water flows into the drains and is conveyed to the airport's wastewater storage units. A similar system is currently under construction at Buffalo-Niagara International Airport in USA. The temporary pads cost less than permanent structures, are portable, and can be assembled on taxiways close to departure runways. The temporary deicing pad consists of a thick rubber mat that can tolerate temperatures ranging from $-50^{\circ} \mathrm{C}$ to $50^{\circ} \mathrm{C}$. The mat is grooved and reinforced with steel cables. The grooves are designed to channel wastewater to existing drainage systems, such as open trenches or trench drains, located at the sides of the mat. The mat can be placed on an asphalt or concrete taxiway and can be moved if necessary. The giant rubber mat is currently in use at Copenhagen International Airport in Denmark, where it is located on a taxiway close to the departure 
runway. The system was installed in 1992 and consists of the rubber mat, a drainage collection system, and wastewater storage tanks. The system is reportedly capable of collecting up to $75 \%$ of sprayed aircraft deicing fluid. The glycol concentration of the collected wastewater is relatively high, typically ranging from $25.8 \%$ to $32.5 \%$ [7].

\subsection{Glycol Recycling}

Due to the high biochemical oxygen demand exerted by glycol-based ADFs, many wastewater treatment plants (WWTP) either refuse to accept ADF-contaminated wastewater from airports or charge high fees for its treatment. To alleviate this problem and meet environmental requirements, several Europe and USA airports now recover glycol from ADFcontaminated wastewater. Glycol recycling offers airports the additional benefit of offsetting some of their treatment costs by generating revenue from the sale of the recovered glycol. Recycling systems rely on a series of standard separation techniques to remove water and suspended solids and, in some cases, surfactants, corrosion inhibitors, and other additives from ADF-contaminated wastewater. The typical glycol recycling system is operated as a batch process due to the variation in influent composition. The glycol recycling process generally consists of several steps, which may include filtration, ion exchange, nanofiltration, flocculation, reverse osmosis, evaporation, and distillation. Since that time, interest in glycol recovery has increased, and today on-site recycling of ADF-contaminated wastewater is successfully performed at several USA and Europe airports, including Denver International Airport in USA, Bradley International Airport in USA, Minneapolis-St. Paul International Airport in USA, Munich Airport in Germany, the Oslo Airport in Norway and the Lulea Airport in Sweden. The system was designed to collect wastewater from aircraft deicing and anti-icing operations with the highest possible glycol concentration by minimizing dilution from precipitation. The system installed at the Munich Airport, for example, collects runoff with an average glycol concentration of 18.6\%. Facility is located at the Munich Airport and can process $6.0 \mathrm{~m}^{3} /$ hour. The systems installed at the Lulea and Oslo airports are smaller than the Munich system and have capacities of $0.4 \mathrm{~m}^{3} /$ hour and $2.4 \mathrm{~m}^{3} /$ hour, respectively. Most glycol recovered from aircraft deicing/anti-icing operations is sold to chemical manufacturers for use in other glycol-based products. Recovered propylene glycol is used in several industries, including coatings, paints and plastics. Recovered ethylene glycol is used primarily as anti-freeze in the automobile and coal industries and as a feedstock in the manufacture of polyester fibers for the garment industry. At some European airports, recovered glycol is reused as an aircraft deicing fluid after the addition of wetting agents and corrosion inhibitors [7].

\subsection{Mobile Pumping Station with Fluid Concentration Sensor}

A trailer-mounted, computer-controlled pumping unit capable of measuring the glycol concentration of the wastewater and diverting it, based on glycol content, to one of three designated storage tanks. The unit is currently in use at Bradley International Airport in Connecticut, USA and Washington Dulles International Airport in Virginia, USA. Mobile Pumping Station consists of a diesel engine, two pumps, a microprocessor, two refractometers, two temperature probes, three flow meters, and three fluid discharge ports with automated valves. The wastewater enters the unit through two flexible hoses attached to ports at the rear of the unit. The hoses are connected to two submersible, self-priming, hydraulic pumps. The pumps may be used to pump ADF-contaminated wastewater from sumps, tanks, or dammed storm water drainage pipes. After entering the unit, the wastewater passes through a refractometer and temperature probe. The refractometer measurements are used to calculate the glycol concentration of the wastewater. Measurements are made once per second and recorded by the microprocessor. Wastewater temperature is measured continuously by the temperature probe, recorded by the microprocessor, and used for making temperature compensations in calculations of glycol concentration. The microprocessor analyzes the data once per time period (e.g. every $15 \mathrm{sec}$ ) and opens and closes valves to the discharge ports based on the glycol concentration. The unit has three discharge ports. One discharge ports is used for discharging wastewater with low and medium glycol concentrations. Two discharge ports are used for discharging wastewater with high glycol concentration (typically greater than 15\%) [7].

\section{Airports polluted runoff treatment schemes}

\subsection{Munich Airport, Germany (MUC)}

At Munich Airport, a system of drainage channels connected to underground pipes is used to collect contaminated surface runoff from the runways and convey it to a wastewater storage complex. The storage complex consists of an underground concrete storage basin with a capacity of $73000 \mathrm{~m}^{3}$ and a lined detention basin with a capacity of $95500 \mathrm{~m}^{3}$. Wastewater from the storage complex is discharged at a controlled rate to a local wastewater treatment plant. Contaminated surface runoff from the airport's taxiways is also collected and treated on site. At the Munich Airport, contaminated runoff from the airport's taxiways is collected and treated by a specially designed biodegradation system installed approximately $0.3 \mathrm{~m}$ beneath the taxiway surface. This system consists of two layers of impervious fabric enclosing a $1 \mathrm{~mm}$ thick layer of bentonite powder. The top fabric layer is overlain with a layer of loosely packed sand, which is seeded with bacteria to biodegrade aircraft and pavement deicing/anti-icing chemicals [7]. ADF-contaminated wastewater is collected and treated by the typical glycol recycling system. 


\subsection{Stockholm-Arlanda Airport, Sweden (ARN)}

Stockholm-Arlanda Airport installed a high-density polyethylene membrane with a bentonite and sand lining beneath the airport's new runway to prevent seepage of aircraft and pavement deicing/anti-icing chemicals into an aquifer that lies directly beneath the runway. The membrane collects surface runoff from the runway and diverts it to a storm water drainage system. The membrane is monitored using leak detection equipment and groundwater monitoring wells [7].

\subsection{Albany International Airport, Albany, $N Y(A L B)$}

Albany Airport's treatment system consists of two identical units. The airport diverts runoff from deicing operations into a lagoon. Albany International Airport operates an anaerobic biological treatment system consisting of two fluidized bed biological reactors. Personnel at the facility then pump water from the lagoon to one anaerobic unit or the other for treatment (Fig. 1). The airport generally operates the two treatment systems in parallel, but sometimes runs them in series. Each unit is $4.3 \mathrm{~m}$ in diameter, $10.5 \mathrm{~m}$ in height, and packed with 10 tons of granular activated carbon. The treatment system was constructed in 1998 and is preceded by a total of $50000 \mathrm{~m}^{3}$ of deicing surface runoff water retention and equalization (retention ponds and a storage tank). The airport collects and treats approximately $70 \%$ of all ADF applied. The treatment system was designed to meet the Airport Authority's design-build performance specifications. These requirements included: 1) a minimum influent flow rate of 450 liters per minute (an annual total of $141000 \mathrm{~m}^{3}$ ), 2) reduction of the propylene glycol concentration from an average of between 4.800 and $7.500 \mathrm{mg} / \mathrm{L}$ to below the detection limit of $1 \mathrm{mg} / \mathrm{L}$, and reduction of chemical oxygen demand (COD) by greater than $90 \%$. Deicing surface runoff water is recirculated through the unit to increase the residence time and equalize influent characteristics. Under anaerobic operating conditions, glycol is converted primarily to methane gas, carbon dioxide, and biomass. Some glycol is also converted to propionic acid. The system is self-sustaining by reusing methane for process and space heating. At the end of each unit, regardless of whether the system is in parallel or series, the airport monitors COD concentrations each morning by collecting grab samples to evaluate the treatment performance (Fig. 2). After this step, the airport typically directly discharges waste into Shaker creek. As a consequence, the airport is required to meet stringent limitations when it discharges directly to the creek. Final effluent is stored prior to either commercial spray irrigation to the airfield or discharge to the WWTP during winter months. The system includes separators to capture and return carryover bed carbon. Excess biomass, which is too fine to be removed by the separators, exits with effluent for discharge through airfield spray irrigation. In warmer weather, the airport sometimes uses the treated wastewater for irrigation. In addition, the airport has the capability of discharging to a WWTP, although it seldom uses this discharge mechanism [2].

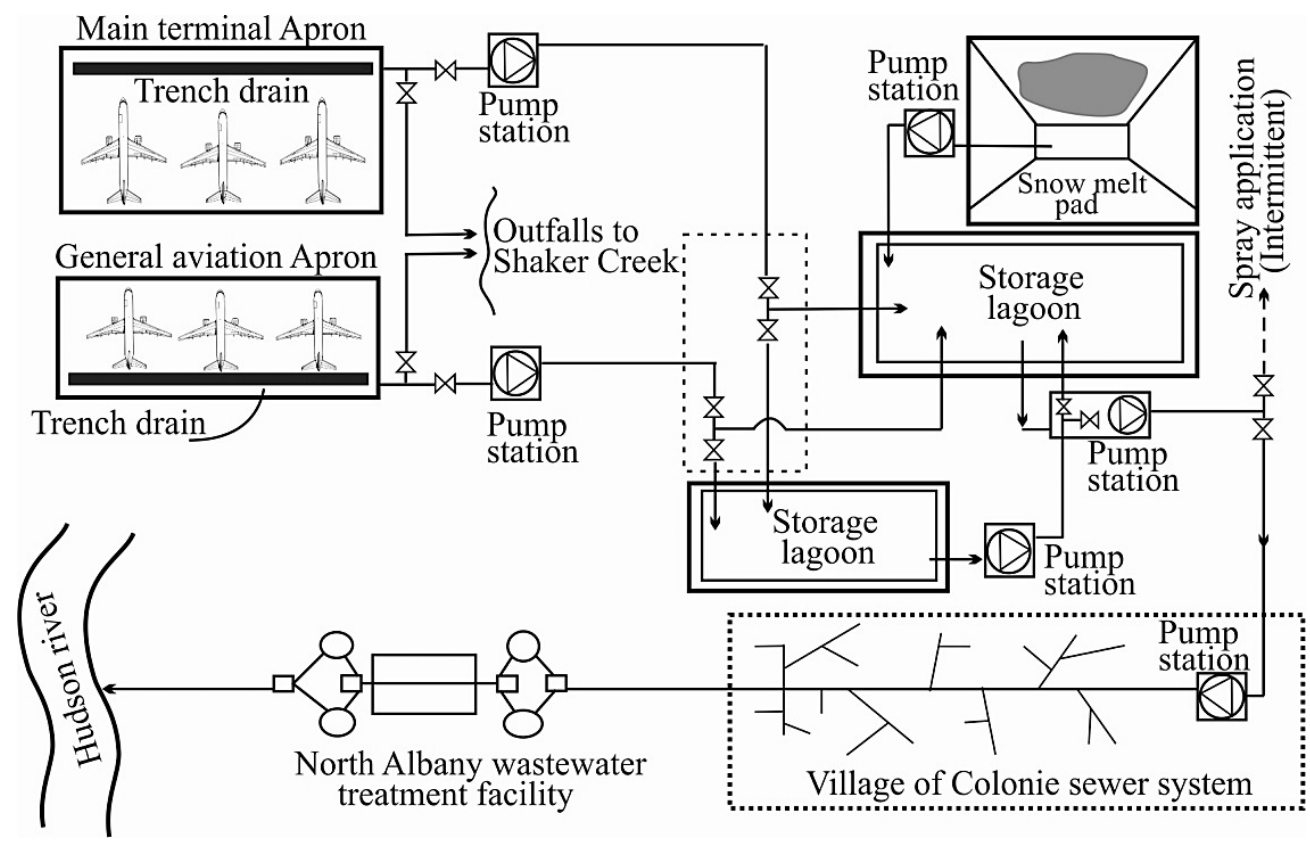

Fig. 1. Simplified drawing of Albany treatment scheme [2] 


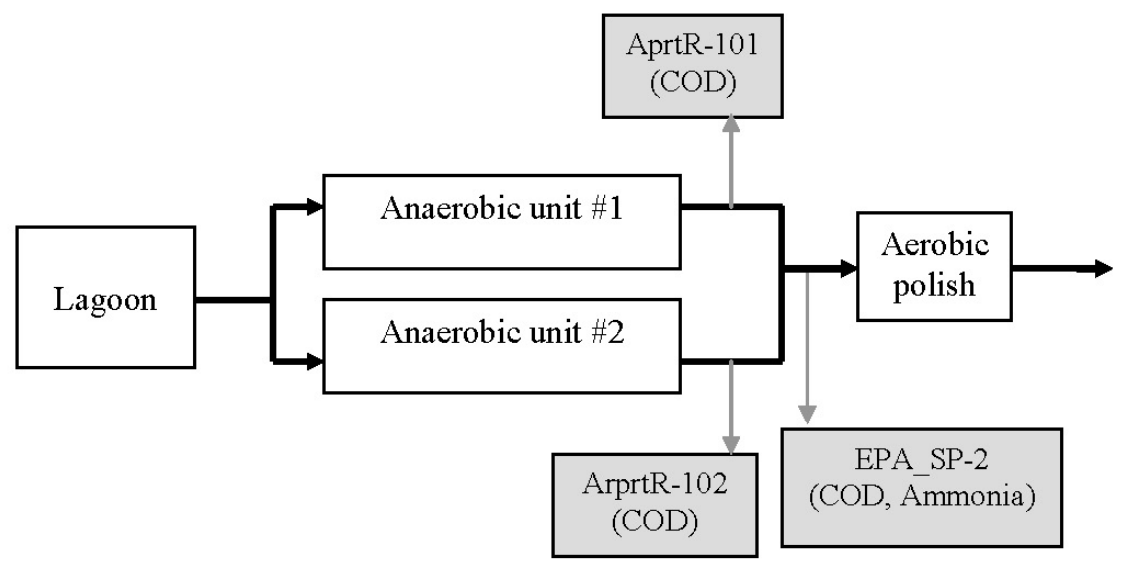

Fig. 2. Simplified drawing of Albany biological treatment system and sample points [2]

\subsection{Syracuse Hancock International Airport (HIA)}

The Syracuse Hancock International Airport (HIA) is a medium-sized regional airport serving the city of Syracuse, New York, USA. The airport handles approximately 150000 operations annually and over 2000000 passenger enplanements. Growth in air traffic at the airport recently led to the construction of new terminal facilities and an advanced deicing waste management system. From October to April the airport receives an average of $534 \mathrm{~mm}$ of precipitation as sleet, freezing rain, and snow [8]. Consequently, deicing fluid usage at the airport is high relative to air traffic. In an average year the airlines operating out of the airport apply approximately $727 \mathrm{~m}^{3}$ of concentrated aircraft deicing fluid, all of it PG based. The deicing waste management facilities at the HIA consists of three centralized or remote deicing pads with collection facilities, a snowmelt pad for contaminated snow, three open storage/treatment lagoons, and concentrate storage tanks [8]. Runoff from the central pads is directed via pump stations and force mains to the storage facilities, which are located on the perimeter of the airport grounds. An in-line total organic carbon (TOC) analyzer at this location is used to detect glycol concentrations, and material over $15 \%$ glycol is diverted to the concentrate storage tanks, while material less than $15 \%$ glycol is directed to the lagoons. A schematic of the system is shown in Figure 3. The treatment and disposal of glycol wastes at HIA is carried out during the summer. Stored wastewater in the three open storage lagoons is augmented with nutrients and buffer, seeded with microorganisms, and then aerated using floating high speed mechanical aerators. After aeration and treatment are sufficient to reduce the waste $\mathrm{BOD}_{5}$ to less than $20 \mathrm{mg} / \mathrm{L}$, the aerators are turned off, biosolids produced during aeration are allowed to settle, and the supernatant is discharged directly to the adjacent waterway. Residual biosolids formed during the treatment process are ultimately collected from the bottom of the lagoons and transported to the County treatment plant for treatment and disposal [2].

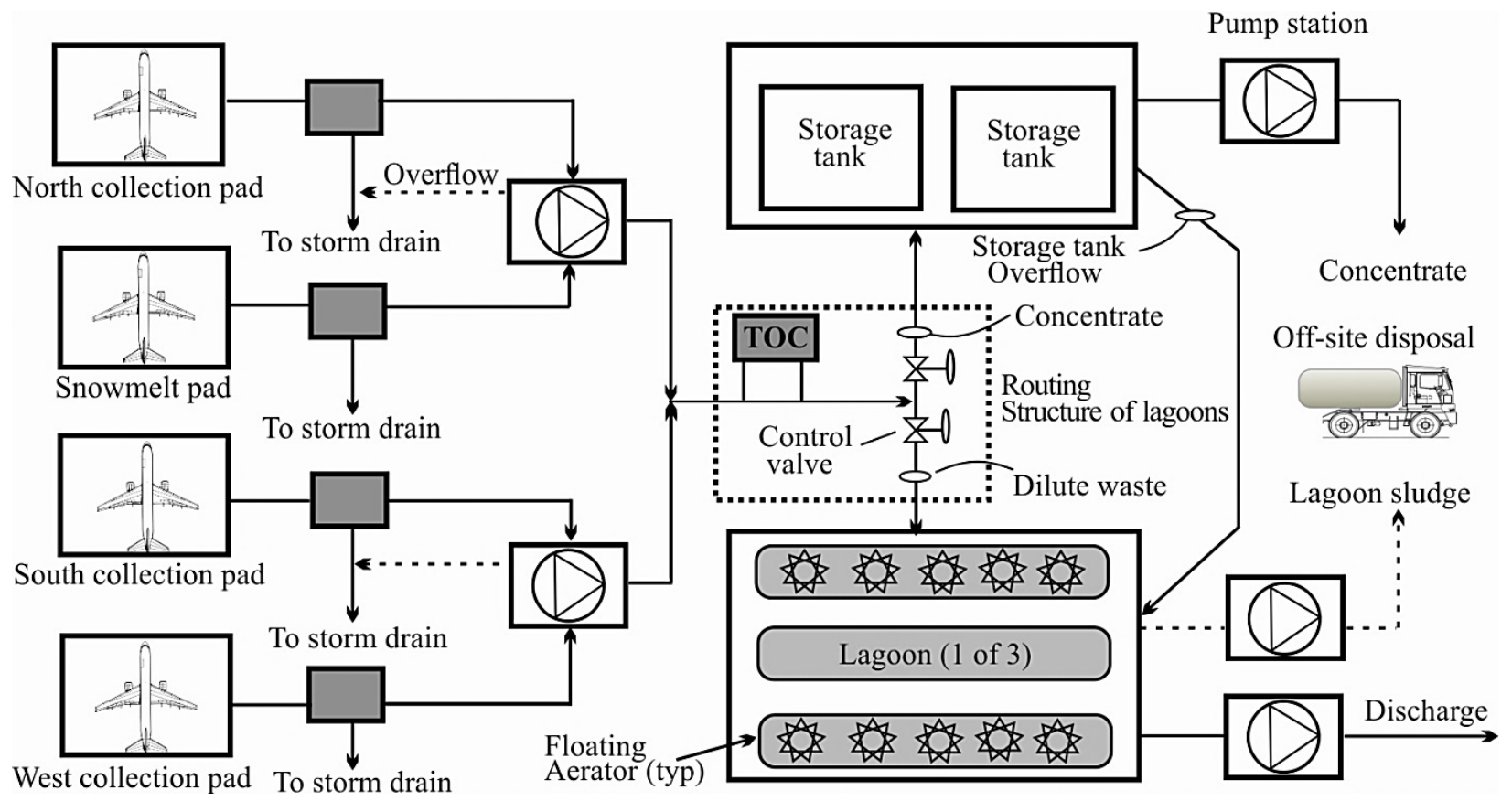

Fig. 3. Simplified drawing of Syracuse Hancock international airport treatment scheme 


\subsection{Zurich Airport (ZRH)}

Zurich Airport is Switzerland's main airport. It has approx. 270000 aircraft movements per year and a total area of 800 ha of which 450 ha are green and 350 ha are sealed areas. The rainwater runoff from the sealed areas is 2.2 million $\mathrm{m}^{3}$ per year [9].

At Zurich Airport alcohols, as well as urea in small quantities, are utilized for de-icing in order to maintain the air traffic during winter. For the disposal of de-icing effluents three TOC concentration levels are distinguished (Fig. 4).

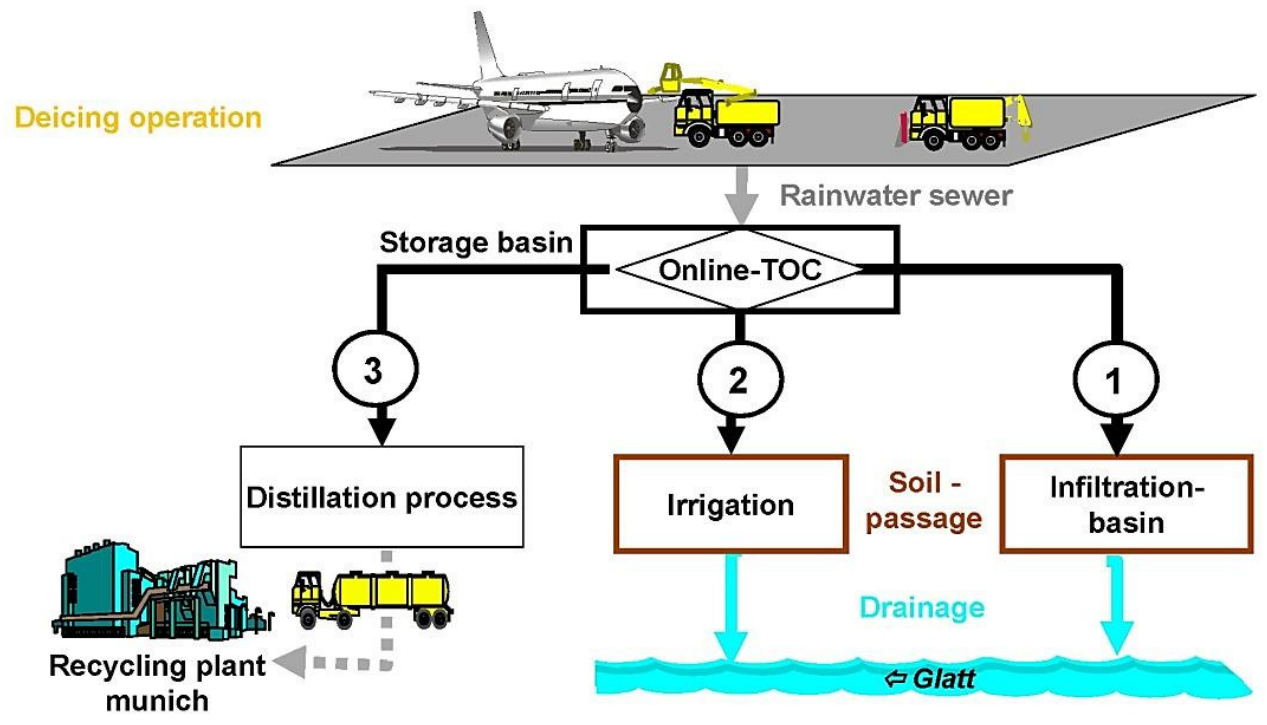

Fig. 4. Simplified drawing of Zurich airport treatment scheme

Less than $20 \mathrm{mgC} / \mathrm{l}$ is discharged directly into a water course, meeting the legal regulations. Very high concentrated effluents are used for the denitrification process in a sewage treatment plant. To dispose of the main part of deicer wastewater in between those two limits a new, groundbreaking and cost-effective (investment and maintenance) method was developed which has been successfully applied since winter 2000-2001. The de-icing effluents are irrigated onto the surrounding green areas and decomposed by microorganisms in the soil in a natural way. The intensive monitoring proves that a near-total TOC degradation (98.3-99.8\%) is obtained [9]. The de-icing effluents are collected by the sewage system in storage reservoirs where pumps feed them into the irrigation system. A total of 20.5 ha are equipped with heated pop-up sprinklers. The irrigation method is effective even on snow and at low temperatures $\left(-15^{\circ} \mathrm{C}\right.$ air temperature). The largely automated procedure is computer-controlled and supplies data for an optimum operation.

The plant consists of: central control station, control system, 7 storage tanks with technical premises, hydraulic devices, 9 additional stations, 20.5 ha irrigation areas where irrigative devices with engineering lines are equipped, 4 settling tanks with filters, 3 drainage water measurement wells, 3 climatic variables/wind measurement stations, 10 groundwater piezometers, the device of high concentration fractions obtained melting ice.

\subsection{Vilnius International Airport (VNO)}

On the basis of literature survey of airports runoff treatment technologies the pre-project solutions were prepared. Besides, there was prepared a technical project of Vilnius airport surface runoff treatment technology which corresponds to the requirements of Lithuanian Republic standards for surface runoff.

The treatment of surface runoff contaminated with deicing agents in case of low air temperature is important for the majority of world airports situated in northern latitudes. Deicing agents which get into surface runoff are notable for very high oxygen consumption when natural purification process begins. However these substances are not toxic and can be fully removed by soil microbial flora. The products used for the deicing of aircrafts are glycol-based, and for the deicing of runways - acetate-based and formate-based. At the moment Vilnius airport still uses carbamide (urea) the base of which contains nitrogen compounds. When carbamide gets into surface waters they are contaminated with ammonium/ ammonia compounds which are difficult to remove in the course of natural purification. Besides, this substance is more aggressive for the pavement; in order to achieve a desired effect more substance is needed, so it has been decided to change over to acetate-based and formate-based products.

In winter Vilnius airport uses deicing products both for aircrafts and runways, in summer ground service transport drives and surface runoff from the larger half of the airport territory (southern, central, eastern parts) gets into Rudaminele stream. Thus, it has been decided to build surface runoff treatment plant for those parts of the airport whose total area of impermeable pavement together with intended infrastructure expansion is about 50 ha.

Before take-off all aircrafts are deiced at the boarding gates or just within the territory in the aircraft parking place. Customer' task provides that the whole territory of aircraft parking and fuel filling will be contaminated with anti-icing, 
deicing fluids. Vilnius airport authority decided that because of the disposition of existing runways and other infrastructure as well as traffic load at the moment it is impossible to equip special deicing/anti-icing places, pads. The territory from which it is planned to remove the runoff in the project was separated in to 5 zones (Fig. 5).

After the treatment of runways and aircrafts with anti-icing, deicing fluids, contaminated water gets into wastewater collecting networks. This project provides to equip new wastewater networks and to isolate the existing networks so that the flow of contaminated runoff accumulating in winter would be directed to one point in the southern part of the airport. It is planned to equip 3 underground runoff pump stations with immersible pumps (PS 1, PS 2, PS 3), 1 runoff pump station with above ground pumps (PS 5), 2 organic substance sensors (TOC), 1 two-section buffer tank, runoff irrigation system, gravity and pressure storm water networks. The runoff accumulating from aprons is separated from oil and sand with a help of 4 oil and sand separators.

The flow of runoff accumulated in the northern part of the airport is diverted to the southern part through gravity and pressure networks.

From the previously designed apron winter runoff is diverted under gravity through the newly designed pipe. At the beginning of this pipe an overflow well is equipped, the well with a knife gate valve and electrified gear for the disconnection of summer runoff. Behind the knife gate valve an oil-sand separator is fitted up.

From the northern part of the existing apron winter runoff is isolated by knife gate valves with electrified gears. This runoff is directed to the well with TOC sensor. Sensor data is transferred to the central system computer. With a help of this sensor, according to runoff contamination through electrified valves, the runoff is distributed to the existing gravity storm water runoff network or to a new pump station PS 1. From the pump station sump pumps controlled by hydrostatic level meter pump over the runoff to the newly designed pipe in the 1 st zone.

From the eastern and western parts of the airport apron runoff is collected with a help of existing storm water runoff networks. Winter runoff is separated by overflow wells. For the disconnection of this winter pipeline a knife gate valve with electrified gear is fitted up. Behind the well with a knife gate valve oil-sand separator with flow distribution and sample taking wells is fitted up. After the separator runoff is diverted to the pump station PS 2. From this pump station sump pumps controlled by hydrostatic level meter pump over runoff into the existing storm water network. For the treatment of summer storm water runoff the separate oil-sand separator is fitted on the existing line.

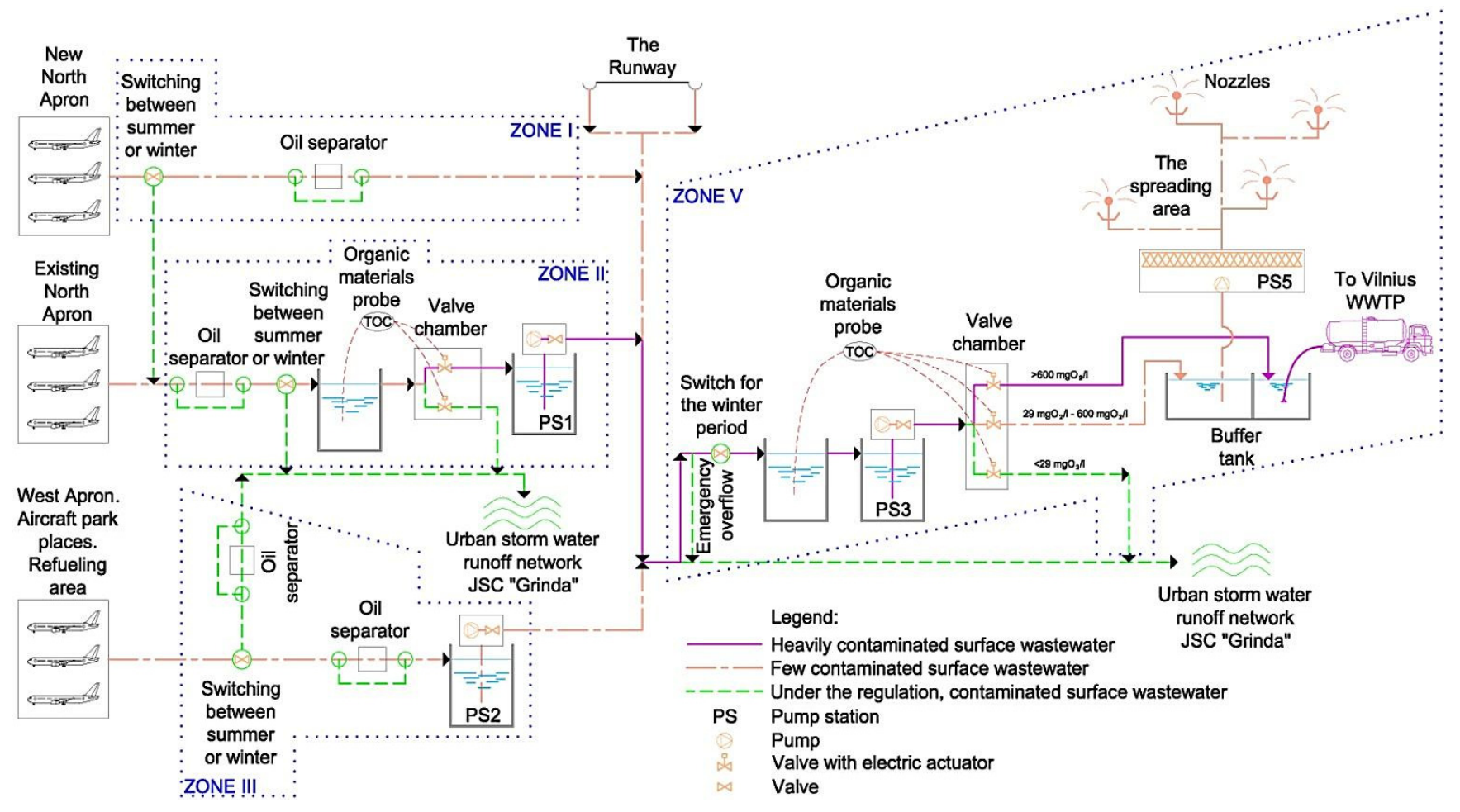

Fig. 5. Simplified scheme of Vilnius airport treatment system

Through the existing and newly designed runoff networks all winter runoff is collected into the sump of the main pump station PS 3 in the southern part of the airport. With a help of organic substance sensor runoff is sorted according to their contamination rate. Sensor data should be transferred to the central system computer. TOC sensor regulates the operation of electrified valves and distributes runoff according to contamination rate into a new tank section intended for highly contaminated runoff, into a new tank section for slightly contaminated runoff, into the existing communal storm water collector. At the beginning very concentrated runoff gets into the networks. This runoff should be directed to the smaller part of the tank, and from there to the city wastewater treatment plants. When melting or rain begins runoff is diluted and should be diverted to the other part of the tank where not very contaminated runoff is accumulated. In case of intensive snow melting or rain, runoff dilutes more and its contamination becomes close to the contamination allowable to discharge 
to surface water bodies. If the sump of the pump station PS 3 is overfilled (the pumps do not manage to pump over too high yield) water through the overflow pipe per gets to a pass-by which is directly connected to the storm water runoff network and gets to the communal storm water collector. In case of huge amount of precipitation the contamination of runoff will be very small because of dilution. Thus, such situation will not have any influence on the general runoff contamination.

From the pump station PS 3 sump pumps controlled by hydrostatic level meter pump over water through the pressure lines into one of the tanks or the communal wastewater collector. If one tank section is overfilled the other section starts filling up. Emergency filling takes place through the overflow device or other pressure line. Hydrostatic pressure-measuring device is provided in a buffer tank. Its intended purpose is to supervise water level in a tank. If water level in a tank exceeds the provided one, runoff delivery to a tank from the pump station PS 3 is disconnected. In case if runoff inflow to the pumphouse NS 3 still takes place, only one valve to the communal wastewater collector in opened regardless contamination. If water level is lower than operating level the pumps of the pump station PS 5 are disconnected. The data of hydrostatic level meter will be transferred to the central system computer. Inevitably, a small quantity of silt and sand will appear which settle down to the tank bottom and it will be necessary to remove this silt from time to time taking it out to the dump or the main city wastewater treatment plants. The main objective after snow melting is to pour the accumulated water through the sprinkler system over green areas. When the stationary sprinkler system is switched on tank emptying begins.

Sprinkler system is powered by dry type pumps fitted up in the pump station PS 5 equipped at the tank. The pumps power the sprinkler system through electrified valves by separate groups. It is impossible to indicate exactly when the sprinkler irrigation system should be used. The optimal time of the sprinkler system switch on can be ascertained after longer usage of this system. The purpose is that accumulated water should be kept in the tanks as long as possible till the warmer season, because in case of favorable weather conditions biodegradation process in soil takes place quicker. However, that also should be ascertained in the course of exploitation. The disposition of the sprinklers and pipes of the irrigation system corresponds to hydraulic calculations; however it will be corrected during the equipment. When the runoff seep through the layers of filtering ground pollutants dissolve and are removed in the course of different physical, chemical and biochemical processes and reactions. The example is the system of irrigation with surface runoff which is equipped in Zurich airport. According to the data of the conducted potassium acetate researches it has been found out that the highest runoff treatment efficiency takes place in 20-30 cm soil layer. The microorganisms existing in this layer can purify runoff up to $80-90 \%$. However in order to avoid the pollution of underground water poured out runoff should be absolutely purified. In the above-mentioned Zurich airport system the layer of complete purification (100\%) is about $80 \mathrm{~cm}$. In case of high level of ground water such system should be supervised and controlled. When water level rises above $80 \mathrm{~cm}$ the irrigation system should be switched off.

The part of the buffer tank intended for the accumulation of mostly contaminated runoff should have taken away. For this purpose a transitional tank is designed, from which runoff should be pumped out into a sewage truck and taken out directly to the city wastewater treatment plants.

\section{Conclusions}

Airports and airlines deal with multiple objectives and are challenged with multiple constraints when it comes to airfield pavement and aircraft deicing and anti-icing. To ensure wintertime flight safety, large quantities of propylene glycol and ethylene glycol based products are used to deice aircraft. In addition, urea and a variety of acetate and formate based products are used to deice runways and taxiways. However, the majority of these compounds exert significant oxygen demands when introduced into natural waterways.

There are several systems for the treatment and disposal of deicing runoff. These systems are divided into three primary categories: off-site, onsite, and recovery options. The off-site category consists of systems where the airports surface runoff into a sanitary sewer system to a wastewater treatment plant for treatment or pay for trucking to a treatment/disposal facility. The on-site category consists of aerobic and/or anaerobic treatment facilities or soil based schemes that can be constructed at the airport for the pretreatment or treatment and disposal of the deicing runoff. The recovery category utilizes filtration, reverse osmosis, and distillation to recover glycol from runoff.

In order to determine the best technology requires a lot of complex research, building on the literature describing best practices, adapting the technology to local weather, geology conditions, topography, combine the solutions to the operators of aircrafts, airport administration.

In winter Vilnius airport uses deicing products both for aircrafts and runways. Surface runoff from the larger half of the airport territory (southern, central, eastern parts) gets into Rudaminele stream. Thus, it has been decided to build surface runoff treatment system for the area of about 50 ha. This project provides to equip new wastewater networks and to isolate the existing networks so that the flow of contaminated runoff accumulating in winter would be directed to one point in the southern part of the airport and treated there. It is planned to equip 3 underground and 1 above ground runoff pump stations, 2 organic substance sensors, 1 two-section buffer tank, runoff irrigation system, gravity and pressure storm water networks, 4 oil and sand separators. 


\section{References}

[1] Valarezo, W. O., Lynch, F. T.; McGhee, R. J. 1993. Aerodynamic performance effects due to small leading-edge ice (roughness) on wings and tails, Journal of Aircraft 30: 807-812. http://dx.doi.org/10.2514/3.46420

[2] Switzenbaum, M. S.; Veltman, Sh.; Schoenberg, T.; Durand, C. M.; Mericas, D.; Wagoner, B.1999. Best Management Practices for Airport Deicing Stormwater. University of Massachusetts/Amherst Water Resources Research Center. Workshop. Publication No. 173.

[3] Loehr, R. C.; Jewell, W. J.; Novak, J. D.; Clarkson, W. W.; Friedman, G. S. 1979. Land application of wastes. Van Nostrand Reinhold New York.

[4] Haines, J. R.; Alexander, M. 1975. Microbial degradation of polyethylene glycols, Journal of Applied Microbiology 29: 621-625.

[5] Klecka, G. M.; Carpenter, C. L.; Landenberger, B. D. 1993. Biodegradation of aircraft deicing fluids in soil at low temperatures, Journal Ecotoxicology and Environmental Safety 25(3): 280-295. http://dx.doi.org/10.1006/eesa.1993.1026

[6] McGahey, C.; Bouwer, E. J. 1992. Biodegradation of ethylene glycol in simulated subsurface environments, Journal Water Science \& Technology 26(1-2): 41-49.

[7] Barash, Sh.; Covington, J; Tamulonis, Ch. 2000. Preliminary Data Summary Airport Deicing Operations. United States Environmental Protection Agency Office of Water. Washington, DC 20460 EPA-821-R-00-016.

[8] Everett, C.; Geisser, D.; Walker, K. 1997. Deicing system at Syracuse: Winter operations, regulations, and water quality, Paper presented at AAEE 69th Annual Conference and Exposition, Minneapolis/St. Paul.

[9] Jungo, E.; Schöb, P. 2006. Disposal of Zurich airport's de-icing effluents by irrigation, Journal Water 21: 51. 